\title{
E.A. Ходжаева
}

\section{Мусульманская молодежь \\ измерить или понять?*}

Актуальность социологических исследований религиозности россиян обусловлена существующим в стране «социальным» заказом. Не только академическое сообщество, но также сами религиозные организации (наиболее крупные из них) и различные государственные структуры заинтересованы в получений сведений о том, сколько же в стране верующих и какова степень их вовлеченности в сферу воздействия религиозных институций. Объективным источником этого «социального» заказа является, на наш взгляд, прежде всего отсутствие религиозной статистики приверженцев тех или иных религий и религиозных направлений и течений. В условиях, когда о развитии тех или иных конфессий мы можем судить лишь по числу зарегистрированных организаций, понятны имеющиеся в политических и околонаучных кругах спекуляции относительно числа верующих. В частности, широко распространен «этнизированный» подход к определению религиозной идентичности: когда всех русских, украинцев, армян, грузин и пр., номинируют православными, а всех татар, башкир, казахов, чеченцев и др. - приписывают к мусульманам [Филатов, Лункин, 2003]. Этой же стратегии придерживаются представители наиболее крупных религий, завышая тем самым число верующих и риторически обосновывая значимость своего символического присутствия в общественной жизни современной России. Одновременно еще одним источником социального заказа является, на наш взгляд, исследовательский интерес со стороны академического сообщества. Желая отказаться от нормативного принятия всех этнических групп приверженцами той или иной религии, социологи изыскивают любые возможности оценить масштабы и характер религиозности соотечественников. В качестве основных подходов в современной эмпирической социологии можно выделить три направления сбора информации о религиозной жизни россиян: '

* | Статья подготовлена в при поддержке РГНФ (грант 08-03-00272а) 
- проведение массовых обследований населения [Старые церкви, 2000; Новые церкви, 2008, Мусина, 2007];

- статистический подсчет посещений церковных служб [Коробко, 2009];

— проведение качественных исследований в приходских сообществах ${ }^{2}$.

В тексте статьи будет представлена методологическая саморефлексия относительно результатов исследовательского проекта «Динамика религиозности в контексте изменения этнического самосознания молодежи Республики Татарстан в 2000-х» (РГНФ, номер проекта 08-03-00272a), обобщившего, с одной стороны, результаты массовых социологических опросов молодежи в республике, проведенных в 2001, 2004 и 2009 гг. ${ }^{3}$, а с другой — данные, полученные методом глубинного интервью и фокус-групп с молодыми людьми и девушками, практикующими исламский образ жизни в городах Татарстана (полученных с 2000 по 2008 гг.) $)^{4}$.

Основной вопрос данной статьи состоит в том, как и что мы можем понять о молодых мусульманах и их религиозности, опрашивая их «количественно» и/или «качественно».

Мы, совместно с Е.А. Шумиловой, выделяем пять компонентов религиозности: 1) идентификационную; 2) эмоциональную; 3) концептуальную; 4) структурирующую поведение и 5) структурирующую сознание [Ходжаева, Шумилова, 2008].

1. Идентификационная составляющая - это осознание человеком своей принадлежности к определенной конфессии. Конфессиональная идентификация является важным этапом в становлении конфессиональной религиозности.

2. Эмоциональная составляющая, к которой мы относим весь спектр эмоций, порождаемых верой: это может быть ощущение близости

\footnotetext{
2 | См., например, доклады международной конференции «Приходы и общины в современном православии: корневая структура российской религиозности» (Центр изучения религий РГГУ, 14-15 октября 2010).

3 | Исследование 2001 г. осуществлено в рамках проекта «Процесс исламизации в Татарстане: влияние на социальную стабильность и формирование новых идентичностей молодежи» (2000-2002 гг., рук. Г.М. Мансурова, при поддержке Фонда Copoca, RSS/OSSF № 2071/1534/2000). В 2004 г. опрос молодежи в Татарстане был проведен в рамках исследовательского проекта «Влияние возрождения ислама на установки молодежи в межэтническом взаимодействии» (2003-2004 гг., рук. Е.А. Бондаренко, при поддержке Фонда «Мегапроект» ПФ0). И наконец, исследование 2009 г. было проведено в рамках проекта «Динамика религиозности в контексте изменения этнического самосознания молодежи Республики Татарстан в 2000-х гг.», поддержанного РГНФ (номер проекта 08-03-00272а). Во всех опросах в основе лежала стратифицированная выборка, которая составлялась с учетом квот по полу, возрасту, месту жительства и роду занятий. Респонденты отбирались по кластерному принципу по месту учебы, работы, или, как в случае с безработными, на бирже труда и по месту жительства. Все опросы проводились в режиме самозаполнения: вопросы веры являются интимными, и необходимость обсуждения их с интервьюером, на наш взгляд, уменьшает степень искренности респондентов. В Татарстане в 2001 г. были опрошены 1026 человек в возрасте от 15 до 29 лет, из которых $54 \%$ - назвали себя татарами, $40 \%$ - русскими, а $6 \%$ либо выразили свою принадлежность к другим этническим группам, либо указали смешанную этничность или не указали ее вовсе. В анкетировании 2004 г. приняли участие 905 человек того же возраста. Из них с татарским этносом себя ассоциировали 48 \%, с русским $42 \%$, иную или смешанную этническую идентичность указали 5 \% опрошенных молодых людей, и отказ в своей этнической идентификации выразили 5 \% участников опроса. Опрос 2009 г. охватил 1006 человек того же возрастного сегмента, из которых $51 \%$ назвали себя татарами и $39 \%$ - русскими.

4 | 51 глубинное интервью 2000-2001 и 2008 гг., две фокус-группы (2004 г.) с молодыми мусульманами.
} 
к Богу, признание человеком правильности религиозного учения, мистическое осознание красоты и взаимосвязанности всего сущего, озарение, блаженство и т.п. чувства. Эта составляющая не поддается измерению в массовых опросах, однако хорошо прослеживается в глубинных интервью с верующими, создает их особое настроение.

3. Концептуальная составляющая, включающая в себя свободное владение основными религиозными концептами, употребление их в ситуациях речевого взаимодействия и объяснение с их помощью явлений повседневной жизни. На более глубоком уровене концептуальная составляющая проявляется в знании, понимании и принятии непреложности доктринальных основ религии.

4. Структурирующая поведение составляющая. Здесь можно заметить, что ритуальная религиозная практика структурирует повседневную жизнь верующего на глубинном уровне. Такие ежедневные обряды, как, например, чтение молитвы, создают основу упорядочивающего повседневность расписания дня. Обрядовая составляющая определяет также наполнение религиозной атрибутикой повседневного пространства верующего: выбор определенного вида одежды, ношение амулетов, оберегов, организация согласно религиозным нормам жилищного пространства и т.д. Соблюдение праздников, постов, посещение храмов и мест паломничества расписывают жизнь верующего в течение всего года и в масштабах всей жизни. На социальном уровне структурирующая поведение составляющая выражается в соблюдении традиций, обрядов и праздников, в участии в жизни религиозной общины и способствует инкорпорированию человека в сообщество единоверцев.

5. Структурирующая сознание составляющая - это интериоризация (усвоение) верующим религиозных ценностей: приоритетов и целей, к которым стоит стремиться; моделей правильного поведения; представлений о чертах характера, которые следует в себе воспитывать. Религиозные ценности предъявляются верующему в виде прямых указаний и требований, или могут раскрываться метафорически через сказания и притчи. Структурирующая сознание компонента религиозности проявляется в стремлении следовать религиозным ценностям в повседневной жизни и в желании их распространять.

По опыту наших исследований, метод массового опроса, даже нацеленный на изучение религиозного опыта, способен осветить в той или иной степени лишь первую, третью и четвертую компоненты. При этом в каждом случае исследователю приходится решать конкретные методические вопросы. Рассмотрим их более подробно. 


\section{1. Идентификационная составляющая}

Казалось бы, данная компонента религиозности не вызывает особых трудностей при проведении массовых опросов — именно признание себя верующим и причисление себя к мусульманам являются в большинстве подобных исследований достаточными для номинирования участников опросов в качестве приверженцев данной религии. Но здесь возникают первые трудности методического плана и в последующем анализе, которые могут привести к противоречивым выводам. Во-первых, о религиозной идентичности можно спросить по-разному. Можно задать закрытый вопрос (что чаще всего и делается в массовых опросах), а можно задать участникам опроса вопрос-тест, попросив их дать о себе пять ответов на вопрос «Кто я?» (тест М. Куна-Т. Макпартленда), который в классическом виде предполагает 20 возможных ответов. В наших исследованиях мы спросили молодежь Татарстана об их религиозной идентичности обоими способами, признавая, что закрытая и конкретная форма вопроса предоставит нам сведения о религиозной идентификации любой степени интенсивности, тогда как тест «Кто я?» послужит индикатором наиболее высокой степени актуализации религиозности в сознании респондента. Отметим также, что данный вопрос-тест задавался в самом начале анкеты, когда ее тематика еще не была полностью раскрыта перед респондентом.

Итак, на открытый вопрос мы получили следующие ответы относительно мусульманской идентичности: в 2001 и в 2004 г. по 15 человек (чуть более 1 \%) указали в числе прочих ответов, что они мусульмане. К 2009 г. число тех, кто назвал себя в тестовом опросе мусульманами или дал схожие ответы («верю в Аллаха») составило уже 30 человек (почти 3 \%). Необходимо ответить, что в данном случае двукратное увеличение в абсолютных показателях не может быть представлено как индикатор значимого повышения степени актуализированности мусульманской идентичности в молодежной среде, поскольку с точки зрения статистического анализа данных оно находится в пределах ошибки выборки. Мы можем лишь сделать вывод о том, что данная идентичность наибольшей степени актуализирована в сознании лишь незначительной доли молодых татарстанцев.

Таблица 1

Субъективная оценка степени религиозности респондентами, причислившими себя к исламу

\begin{tabular}{|c|c|c|c|}
\hline $\begin{array}{c}\text { Верующий ли } \\
\text { Вы человек? }\end{array}$ & $\begin{array}{c}2001 \\
\text { Указавшие привер- } \\
\text { женность исламу } \\
38 \text { \% по выборке; } \\
\text { из них } 96 \text { \%-- } \\
\text { татары }\end{array}$ & $\begin{array}{c}2004 \\
\text { Указавшие } \\
\text { приверженность } \\
\text { исламу } 41 \text { \% по } \\
\text { выборке; из них } \\
93 \text { \% - татары }\end{array}$ & $\begin{array}{c}2009 \\
\text { Указавшие } \\
\text { приверженность } \\
\text { исламу } 48 \text { \% по } \\
\text { выборке; из них } \\
91 \text { \% - татары }\end{array}$ \\
\hline
\end{tabular}




\begin{tabular}{|c|c|c|c|}
\hline $\begin{array}{c}\text { Да, верующий, } \\
\text { соблюдаю } \\
\text { обряды и } \\
\text { обычаи }\end{array}$ & $6 \%$ & $15 \%$ & $11 \%$ \\
\hline $\begin{array}{c}\text { Да, верующий, } \\
\text { но не соблюдаю } \\
\text { всех обрядов }\end{array}$ & $71 \%$ & $67 \%$ & $70 \%$ \\
\hline Колеблющийся & $8 \%$ & $12 \%$ & $8 \%$ \\
\hline $\begin{array}{c}\text { Неверующий, } \\
\text { но уважаю чувс- } \\
\text { тва тех, кто } \\
\text { верует }\end{array}$ & $9 \%$ & $5 \%$ & $0 \%$ \\
\hline $\begin{array}{c}\text { Неверующий, } \\
\text { считаю, что с } \\
\text { религией надо } \\
\text { бороться }\end{array}$ & $0 \%$ & $0 \%$ & $3 \%$ \\
\hline $\begin{array}{c}\text { Затрудняюсь } \\
\text { ответить }\end{array}$ & $5 \%$ & $2 \%$ & $0 \%$ \\
\hline Нет ответа & $1 \%$ & $0 \%$ & 100 \\
\hline Всего & 100 & 100 & $8 \%$ \\
\hline
\end{tabular}

Распределения ответов на закрытые вопросы о религиозной идентичности оказываются более обнадеживающими для мусульманского сообщества и на первый взгляд подтверждают известный тезис мусульманских лидеров региона о том, что к исламу сегодня приходит все больше молодежи. В 2001 г. к мусульманам себя отнесли 37 \% участников опроса, в 2004 г. - 41 \%, а в 2009 г. - уже почти половина (47 \%). Эти данные можно трактовать как тенденцию увеличения числа адептов ислама в молодежной среде Татарстана. Однако если мы посмотрим на самооценку мусульманами собственной степени религиозности, то обнаружим противоречия. Подавляющее большинство адептов ислама среди татарстанской молодежи (около 70 \%), называя себя верующими, признают, что не соблюдают всех обрядов и обычаев. Доля назвавшихся верующими и соблюдающими обряды и обычаи невысока и составляет в 2000 г. 11$15 \%$ (здесь нужно напомнить, что речь идет лишь о собственной оценке респондентом собственной религиозности). При этом, несмотря на то, что вопрос о религиозной идентификации задавался только тем, кто считает себя верующим или колеблющимся (последних среди назвавшихся мусульманами было незначительное число - 8-12\%) жи, причислившей себя к адептам ислама, нашлись те (в 2001 и в 2009 гг. 8-9 \%), кто считает себя неверующим. Это обстоятельство является свидетельством существующего в сознании определенной части молодежи противоречия с точки зрения догматики ислама, которая понимает под мусульманами, безусловно, только верующих людей.

5 | Точная формулировка вопроса: «Если Вы верующий или колеблетесь, то какой религии Вы придерживаетесь?» 
Таким образом, если перед нами поставлен «социальный заказ» определить долю мусульман среди молодежи Татарстана — то мы сталкиваемся с первой дилеммой: включать или не включать в их число тех, кто одновременно причисляет себя к исповедующим ислам и утверждает, что он неверующий. Если же учитывать при определении доли мусульман еще и обрядовый и когнитивный компоненты религиозности - то задача определить долю мусульман в молодежной среде значительно усложняется.

\section{2. Структурирующая поведение верующего составляющая}

Вопрос о том, следует ли респондент религиозной практике, также можно задать в открытой и закрытой формах. В 2001 г. мы предложили участникам опроса самостоятельно вписать в анкету ответы о том, какие религиозные обряды и ритуалы они соблюдают. Результаты оказались плачевными: более половины (56 \%) из тех, кто причислил себя к исламу, не дали ответа. В 2004 и 2009 г. в анкете был предложен перечень возможных ответов (см. Табл. 2). Оказалось, что даже в этом случае треть опрошенных, назвавшихся мусульманами, не указывает ни одного обряда. Еще одна треть отметила практику обрядов, имеющих социальное значение, чаще всего свадебный обряд и имянаречение. Похоронный обряд и обрезание отмечались, видимо в виду возраста или пола реже - каждым пятым представителем этой группы. Также от одной пятой до трети практикуют некоторые мусульманские традиции - милостыня, посещение мечети. При этом доля тех, кто вовлечен к ежедневную религиозную практику, достаточно низкая - в 2009 г. 5 \%, что в два раза ниже доли тех, кто считает себя верующим и исполняющим все обряды и обычаи (см. Табл. 1).

Таблица 2

Соблюдение мусульманских обрядов респондентами лично, причисливших себя к исламу; по результатам опросов 2004 и 2009 г. ${ }^{6}$ )

\begin{tabular}{|l|l|l|}
\hline $\begin{array}{l}\text { Какие мусульманские обряды соблюдают- } \\
\text { ся Вами лично }\end{array}$ & 2004 & 2009 \\
\hline Никах (свадебный обряд) & $40 \%$ & 39 \\
\hline Жиназа уку (похоронный) & $25 \%$ & $19 \%$ \\
\hline Исем кушу (имянаречение) & $39 \%$ & $36 \%$ \\
\hline Суннат (обрезание) & $20 \%$ & $23 \%$ \\
\hline
\end{tabular}

6 | Мы не приводим здесь данные по опросу 2001 г., поскольку тогда вопрос о личном ритуальном и обрядовом поведении был задан респондентам в открытой форме. Как известно, подобная форма вопроса часто приводит к высокому проценту неответивших. В случае исследования 2001 г. таковых было две трети среди всех опрошенных (62 \%), а среди назвавшихся мусульманами этот показатель составил $56 \%$. 


\begin{tabular}{|l|l|l|}
\hline Ураза & $30 \%$ & $14 \%$ \\
\hline Намаз & $11 \%$ & $5 \%$ \\
\hline Пятничная молитва & $5 \%$ & $5 \%$ \\
\hline Тахарат & $16 \%$ & $13 \%$ \\
\hline Хадж & $2 \%$ & $2 \%$ \\
\hline Закят & $4 \%$ & $8 \%$ \\
\hline Садака & $43 \%$ & $33 \%$ \\
\hline Посещение мечети & $26 \%$ & $27 \%$ \\
\hline Другие & $0 \%$ & $1 \%$ \\
\hline Нет ответа & $30 \%$ & $35 \%$ \\
\hline
\end{tabular}

Ответы респондентов на дополнительные вопросы об их личной религиозной практике, заданные лишь в 2009 г., также подтверждают вывод о том, что доля «практикующих» мусульман среди тех, кто причисляет себя к исламу, довольно низкая. Так, половина этой группы призналась, что практически не молится. Доля тех, кто молится хотя бы раз в неделю, среди молодежи, причислившей себя к мусульманам, составила менее одной пятой, включая совершенно незначительную долю тех (2 \%), кто старается совершать пятикратный намаз.

Диаграмма 1

\section{Частота молитвенных практик респондентов, причисливших себя к исламу (опрос 2009 г.)}

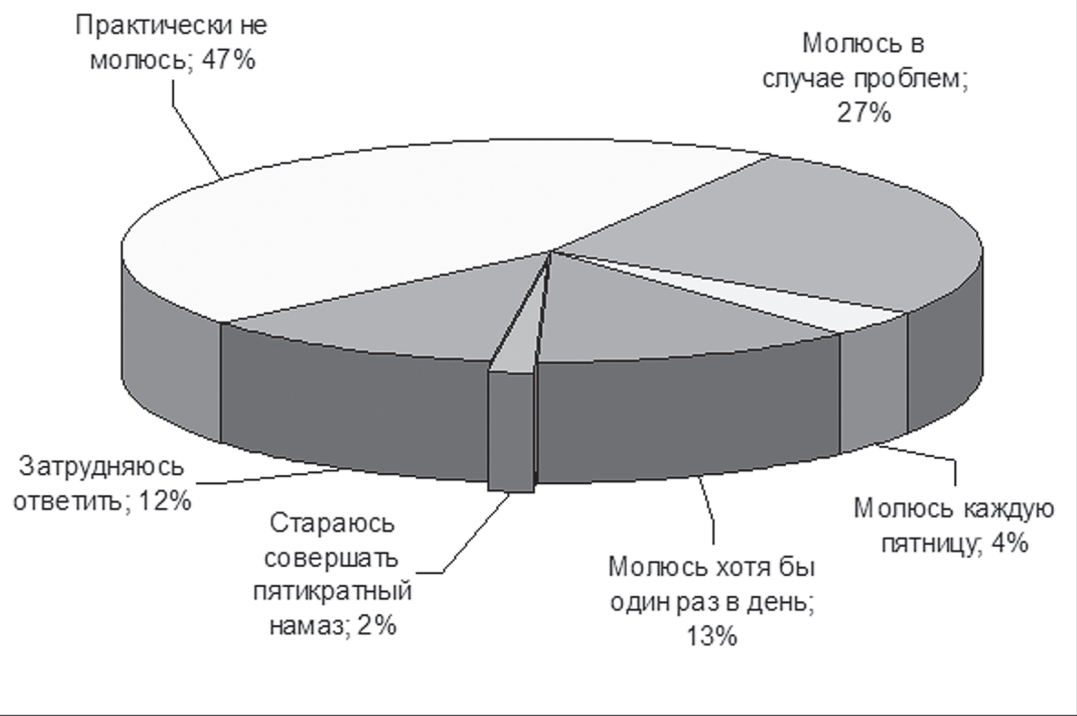


Пост в месяц Рамадан (Ураза) стараются регулярно практиковать 5 \% этой группы молодежи, менее одной пятой ответили, что им не удается поститься ежегодно. Подавляющее же большинство (77 \%) участников опроса, назвавших себя мусульманами, согласно их ответам, не соблюдают пост. Схожая ситуация наблюдается и в связи с религиозными запретами в еде. Только 5 \% данной группы молодежи потребляют разрешенную (халяльную) пищу, еще каждый пятый - старается соблюдать это правило.

Диаграмма 2

Установка на соблюдение запретов в еде среди респондентов, придерживающихся ислама (опрос 2009 г.)

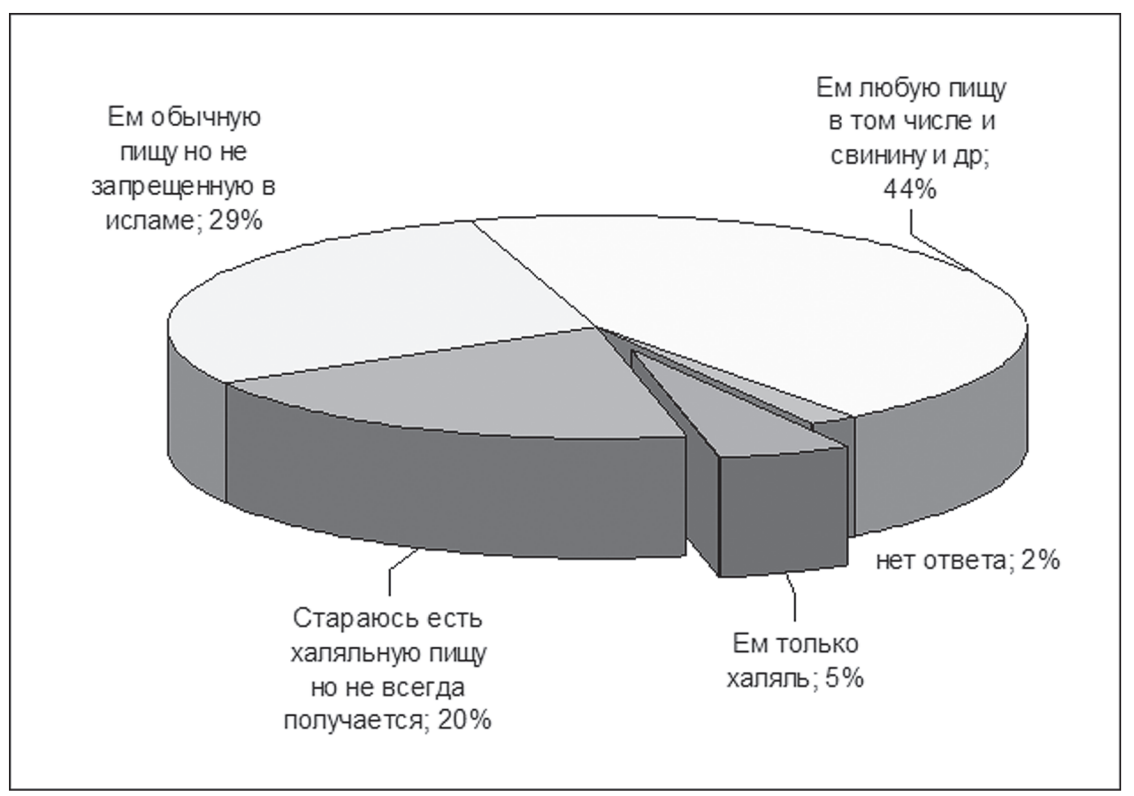

Незначительная доля «практикующих» мусульман прослеживается во «включенности» опрошенных в мусульманские сообщества, поскольку такая включенность подразумевает не только посещение мечети, но также и общение и деятельное участие в жизни общины. Так, только $3 \%$ респондентов, причисливших себя к мусульманам, регулярно обращается к священнослужителям за советом, почти треть делает это редко, и две трети этой группы молодежи, ответили, что никогда не обращались к священнослужителям. Духовный наставник есть у 7 \% данной группы, еще четверть не имеет духовного наставника, но ответила, что нуждается в таком человеке. Остальные (и снова две трети) не испытывают подобной потребности. В 2009 г. почти каждый пятый, 
причисливший себя к последователям ислама, ответил, что помогает мусульманским организациям. Кстати, это больше, чем в начале 2000-х гг.: в предыдущих опросах помощь религиозным организациям указали от 10 до 12 \% этой группы молодежи. В большинстве случаев это финансовое участие, в общей сложности ее отметили двое из пяти, включая и тех, кто под помощью подразумевал милостыню бедным. 8 \% указали, что оказывают такую помощь делами, и 1 \% ответил, что помогает продуктами. Адресатами помощи религиозных организаций с той или иной частотой являются $9 \%$ опрошенных и их семей (часто $-2 \%$, редко - $7 \%$ ).

Таким образом, если рассматривать данные опросов целостно, то можно отметить, что респонденты называли себя исполняющими обряды, имеющие скорее не «личностноориентированное», а «социальное» измерение, т.е. характеризующие:

- либо изменение социального статуса - никах, имянаречение;

- либо значимость ритуала для семейной или, более широко, этнической группы (похоронный обряд, обрезание).

Самой популярной практикой, которая имеет личностноориентированное значение, оказалась милостыня (садака) - ее практикует каждый третий, указавший свою принадлежность к исламу. Четверть таких опрошенных отметила, что посещает мечеть. Такая же доля респондентов нацелена на соблюдение мусульманских запретов в еде. С той или иной степенью регулярности практикуют пост менее одной пятой респондентов, и около 15 \% стараются ежедневно молиться.

Анализ структурирующей поведение компоненты религиозности на материалах массового опроса 2009 г. приводит нас к тому, что доля практикующих мусульман сегодня составляет не более 5 \% (индикатором в данном случае служит доля тех, кто ответил, что читает намаз), поскольку соблюдение других «столпов» ислама (пост в месяц Рамадан, хадж, закят) не всегда обязательны для исполнения.

\section{3. Концептуальная составляющая религиозности}

Эта компонента в методике наших опросов была представлена перечнем как догматических, так и недогматических позиций веры, среди которых респондентам предлагалось выбрать те, которые они считают истинными. Четверо из пяти (83 \%) респондентов (как в целом по выборке, так и среди этой группы) ответили, что верят в Бога. Однако из этого следует, что остальные из причисливших себя к исламу (17\%), не указали своей веры в Бога. В целом к 2009 г. убежденность в основных положениях ислама проявляла меньшая доля представителей этой группы молодежи. Так, в начале 2000-х гг. двое из трех опрошенных, назвавших себя мусульманами, отмечали, что верят в наказание 
за грехи. В 2009 г. доля таких ответов сократилась на треть и составила 44 \%. Существование Ада и Рая в начале 2000-х гг. признавали почти трое из пяти респондентов, причисливших себя к исламу, в последнем опросе эта доля составила лишь треть группы. Бессмертие души в 2009 г. признали почти в два раза меньше назвавших себя мусульманами, чем в начале и середине 2000-х гг. Лишь вера в Судный день осталась разделяемой практически той же частью этой группы молодежи - в 2001 г. его признавала треть молодежи, в 2009 - четверть.

Одновременно группа тех, кто причисляет себя к исламу, теряет убежденность в других (с точки зрения исламской догматики «неистинных») позициях веры. Все меньше молодежи доверяет астрологии и гороскопам, гаданиям и приметам. Особенно резко снизилась вера в положение о переселении душ - в начале 2000-х его придерживалась треть назвавшихся мусульманами, а сегодня лишь $14 \%$.

Таблица 3

\section{Идеи и положения, которых придерживается молодежь, причислившая себя к мусульманам}

\begin{tabular}{|l|l|l|l|}
\hline Верите ли Вы в... & 2001 & 2004 & 2009 \\
\hline В Бога 7 & & & $83 \%$ \\
\hline Наказание за грехи & $65 \%$ & $64 \%$ & $44 \%$ \\
\hline Существование Ада и Рая 8 & $59 \%$ & $58 \%$ & $34 \% / 37 \%$ \\
\hline Бессмертие души & $46 \%$ & $39 \%$ & $20 \%$ \\
\hline Приметы & $36 \%$ & $37 \%$ & $21 \%$ \\
\hline Астрологию, гороскоп & $35 \%$ & $36 \%$ & $19 \%$ \\
\hline Переселение душ & $34 \%$ & $27 \%$ & $14 \%$ \\
\hline Судный день & $35 \%$ & $31 \%$ & $27 \%$ \\
\hline Магия, гадание & $20 \%$ & $24 \%$ & $16 \%$ \\
\hline В ангелов & & & $22 \%$ \\
\hline $\begin{array}{l}\text { Ни во что из выше перечислен- } \\
\text { ного не верю9 }\end{array}$ & \multicolumn{2}{|l|}{$\%$} & $9 \%$ \\
\hline Нет ответа & ,8 \% & $7 \%$ & $0,8 \%$ \\
\hline
\end{tabular}

В рамках данной статьи мы ограничимся рассмотрением только этих вопросов, касающихся концептуальной составляющей религиозности, оставив вне поля нашего внимания вопросы об опыте чтения Корана и религиозной литературы, об установках на получение религиозного образования, об интересе к эзотерическим течениям и пр. Даже приведенные данные позволяют показать широкие возможности в интерпретации наших респондентов как мусульман так и не мусуль-

\footnotetext{
7 | Эта позиция, а такж позиция «В ангелов» задавались только в опросе 2009 г.

8 | Эти позиции в опросе 2009 г. задавались раздельно: «Существование Ада» и «Существование Рая».

9 | Эта позиция задавалась в опросах 2004 и 2009 гг.
} 
ман в зависимости от различных аспектов их веры. Так, если мы будем считать убежденными мусульманами только тех, кто верит в Бога, - то должны уменьшить долю причисливших себя к исламу на 17 \%. Однако если мы будем понимать убежденность, как признание истинным не только существование Бога, но также и других догматических положений ислама, то доля убежденных молодых мусульман составит не больше 20-27 \% (признание бессмертия души и Судного дня).

Качественные методы - в нашем случае глубинные интервью и фокус-группы с представителями группы практикующей мусульманской молодежи - позволяют собрать данные обо всех элементах религиозности. Причем в каждом случае они по-разному актуализированы в зависимости от личности собеседника, его стратегии самопрезентации, ситуации интервью и личности того, кто собирает материал. В итоге исследование, выполненное в рамках «субъект-субъектной» парадигмы позволяет, как ожидается, описать многообразие индивидуальных интерпретационных схем и практик. Самая сложная задача при работе с такими данными - перейти на уровень обобщений разрозненных жизнеописаний и ценностных воззрений. При этом в качественном подходе существует предел генерализации материала. Практическим итогом, например, никогда не станет ответ на вопрос сколько же процентов мусульман в молодежной среде. Однако мы имеем возможность показать и понять «жизненный мир» практикующей мусульманской молодежи.

Рассматривая идентификационную составляющую религиозности, стоит отметить, что самоопределение молодого мусульманина или мусульманки строится в нескольких координатных осях. Во-первых, это традиционное разделение всей уммы на различные направления, течения (мазхабы). Все наши информанты прекрасно осведомлены о своей принадлежности к «людям Сунны» и ханафитскому мазхабу. Следование этому направлению обосновывается чаще всего традиционной приверженностью ему татар, и реже собственным религиозным выбором. Кроме того, в интервью мы практически не встречаем негативного отношения к мусульманам, придерживающихся других направлений и течений, в частности шиизма. Стоит отметить, что в повседневной речи, рассуждая об исламе и о мусульманах в целом, информанты старались не актуализировать догматические расхождения, и мыслили себя и других людей в рамках всех мусульманской уммы: «Я считаю, что это плохо очень много различных течений. Такого быть, я считаю, не должно. Поэтому я себя не отделяю, я говорю “мусульманин”, на этом все» (Казань, 2008, муж., 23 г.).

Обсуждая религиозные и догматические различия между различными направлениями ислама, многие наши собеседники обращались к теме ваххабизма. В условиях навязанной со стороны СМИ интерпретации сторонников этого течения как социальной почвы для радикально- 
экстремистских идей и терроризма, верующая молодежь вынуждена оправдывать себя и свою веру, подчеркивая:

- либо сконструированный характер этого ярлыка, который навешивается на любого мусульманина или мусульманку: «Слова “ваххабизм" вообще не должно быть. Людей следует разделять на хороших или плохих» (Набережные Челны, 2001 г., жен, 19 л.];

- либо оправдывая верующих, причисляющих себя к этому направлению, при этом дистанцируясь от них: «Ваххабизм - это течение ислама... Это не о учение, которое призывает к... плохому, нечеловеческому. Такое же течение, которое призывает верить в Аллаха, и нет там особой такой плохой стороны, чтобы противоречила той жизни, в которой мы живем. То, что там призывает, это все то, что полезно человеку» (Казань, 2000, жен., 22 г.);

- либо указывая на то, что слово «ваххабизм» стало удобным маркером всех несогласных и экстремистски настроенных групп, которые не имеют ничего общего с «настоящими» мусульманами.

Вторым направлением самоидентификации мусульманской молодежи является актуализация следования религиозной практике. Она включает в себя также элементы повседневных типизаций мусульман на «соблюдающих»-«несоблюдающих», «практикующих»«непрактикующих». Примечательно, что именно здесь происходит этнизация группы непрактикующих мусульман. Если в ответах на вопрос о том, связаны ли этничность и религиозность, практически все собеседники отвечали «догматически» верно и корректно, что ислам - это религия не только татар, и любой человек, вне зависимости от этничности или национальной принадлежности, имеет право на вхождение в умму, то при обсуждении непрактикующих мусульман в качестве последних всегда назывались этнические татары. Рассуждая о них, информанты часто используют категорию «этнические мусульмане» для того, чтобы развести в конкретном контексте Татарстана категории соблюдающих и несоблюдающих мусульман и дистанцироваться от последних. Здесь нужно отметить двойственное отношение к этническим мусульманам. С одной стороны, как показано выше, подчеркивается наличие дистанции по отношению к этим людям. Одновременно с этим «этнические мусульмане» рассматриваются практикующими в качестве потенциальной основы для развития ислама в регионе. Так, людям, называющим себя мусульманами, пусть даже по этнической традиции, наши собеседники не отказывают в праве символического вхождения в умму. Здесь говорится о том, что главное, чтобы человек себя считал мусульманином, а за неисполнение предписаний он будет отвечать сам. Кроме того, в интервью нередко высказываются сожаления по поводу того, что татары выбирают другие вероисповедания и религиозные практики, поскольку «этнические мусульмане» рассматриваются как ресурс увеличения числа соверующих. 
Эмоциональная оставляющая религиозности оказывается самым трудным для вербализации компонентом, поскольку она затрагивает весь чувственный опыт верующего. Чаще всего переживаемый в молитве опыт веры описывается в интервью через «очищение», обретение состояния «одухотворенности», «укрепления в вере». Информанты обсуждают, что в мечети или дома в случае коллективной молитвы, когда они совершают намаз семьей, их вера («иман») «сильнее», «крепче». Некоторые информанты отмечали, что не только молитва, но и чтение Корана приносит им несравненные эмоциональные ощущения, которые они описывают как чувство легкости, спокойствия и очищения. Важным моментом для получения уникального эмоционального опыта переживания веры является отказ рационально мыслить в молитве и позволить чувствам проявиться. Некоторым нашим информантам ислам помогает обрести смысл в жизни - не через душевное спокойствие, а через вдохновение.

Отдельным опытом эмоционального переживания является ношение девушками и молодыми женщинами хиджаба. По данной теме в Казани проведено отдельное исследование Д.М. Гараевым [Гараев, 2008], с которым мы в целом согласны в том, что опыт ношения платка является поворотным моментом в судьбе мусульманки, после которого «обратного пути уже нет, все ты решила - ты должна идти до конца» (Казань, 2008, жен., 24 г.). В 1990-х — начале 2000-х гг. в Татарстане, а в других регионах России и по сей день, мусульманка в платке испытывает «общественное внимание», которое может быть как положительным, так и негативным. Практически каждая девушка в хиджабе вырабатывает в себе умение эмоционально закрыться, если находится в незнакомом ей секулярном окружении (на улице, в транспорте и т.п.), чтобы преодолеть излишнее внимание к себе со стороны. Именно в этом контексте молодые мусульманки нередко отмечали, что ношение платка или хиджаба приносит им чувство «защищенности», «отрешенности». Многие воспринимают его как «молчаливый призыв» к исламу. Но в интервью мы не раз встречаем рассказы о том, что некоторые девушки не выдерживают общественного давления или в целом отказываются от исламской идентичности, или перестают носить хиджаб, оставаясь практикующими мусульманками. Однако такие случаи являются, по мнению наших собеседниц, скорее исключением.

Структурирующая сознание компонента религиозности проявляется в усвоении ценностно-нормативного содержания религиозной доктрины. Прежде всего здесь необходимо отметить проявляющуюся во всех интервью установку на традиционализм и патриархальное мировоззрение. Самыми значимыми ценностями для всех собеседников являются семья и брак, подразумевающие уважение к старшим родственникам, традиционное разделение внутрисемейных ролей, при котором мужчине отводится роль основного кормильца семьи, а женщине - хранительницы домашнего очага, заботящейся о детях и муже. 
При этом многие из наших собеседниц-мусульманок работают. Этот факт они комментируют либо собственными стремлениями и разрешением от мужа, либо необходимостью дополнительного заработка в семье. Молодые мусульманки, еще не имеющие детей, в интервью 2008 г. видят свой брак следующим образом: сначала планируется создание основы для будущей семьи («строительство дома», «покупка квартиры», «создание основного капитала»), а только затем рождение детей. После заботы о детях по достижении ими самостоятельного возраста, все респондентки планируют вернуться к работе. В качестве сферы занятости молодые мусульманки выбирают либо роль помощницы мужа в делах, либо «женские» профессии (воспитательница в детском саду, учительница и т.п.), в некоторых случаях научную академическую карьеру.

Юноши-мусульмане также констатировали принятие ими традиционных патриархатных ценностей. Практически все из них, кто старше 20 лет, указывали на то, что нацелены на создание собственного бизнеса. При этом особо декларировалась социальная и религиозная сторона вопроса - бизнес должен не только приносить доход, но и «помогать» людям фактом создания рабочих мест или благотворительностью и т.п.

Наиболее отчетливо ценностно-нормативные ориентиры молодых мусульман проявляются через сравнение собственного образа жизни и мыслей с поведением и мировоззрением большинства молодежи. Мусульманская молодежь не принимает многие аспекты современного стиля жизни сверстников: от ношения модной одежды, оголяющей тело, до практики неофициального сожительства; от курения и употребления алкоголя до установок на незаслуженную собственным трудом, богатую и полную наслаждений жизнь. Подобным негативным проявлениям в среде их сверстников мусульманская молодежь противопоставляет такие, по ее мнению религиозные, ценности, как уважение к старшим, активный труд на благо общества, желание больше помогать другим людям, нежели получать от них. Также стоит отметить прослеживающийся практически во всех интервью очень сдержанный тон верующих при критике негативных явлений или недостойного поведения окружающих или незнакомых им людей.

Структурирующая поведение составляющая проявляется в повседневной жизни молодого верующего. Молодые мусульмане в отличие от своих неверующих сверстников, относятся к религиозным предписаниям и требованиям не как к «ярму» или «тяжести», а как к радости, благословению Аллаха или своему служению. Это проявляется как для предписаний по самым обычным и повседневным аспектам жизни, так и относительно более широких вопросов.

Все наши информанты сказали, что стараются исполнять обязательные требования ислама. Они пятикратно совершают намаз (могут прочесть его в учебной аудитории или в другом пригодном помещении в вузе или на работе), соблюдают пост в месяц Рамадан, в той ли иной 
мере участвуют в жизни религиозных общин или организаций. Соблюдение запретов в еде и в общении (например, отказ от посещения молодежных мероприятий и событий, где люди употребляют спиртное) является обязательным условием их жизни.

Здесь также нужно указать на различие между теми молодыми мусульманами, которые пришли к вере самостоятельно (иногда даже вопреки мнению родителей), и теми, кто был воспитан в религиозной атмосфере. У последних поведенческая компонента религиозности формируется постепенно и в согласии с нормами жизни их семейной референтной группы. В то же время, информанты, пришедшие к вере самостоятельно, указывают на неприятие со стороны неверующего окружения (родителей, родственников, друзей). Именно таким верующим в период неофитства приходится постепенно преодолевать привычный ранее секулярный образ жизни, изменять интересы и приоритеты, жертвуя иногда общением с прежними друзьями. Нередко отмечается, что информантам удается изменить своим поведением внешнее окружение (в вузе, в рабочем коллективе, среди неверующих родственников и знакомых. При этом указывается, что воздействовать на других людей предпочтительно не с помощью открытой агитации и нравоучений, а собственным примером, когда окружающие люди, учитывая стиль жизни мусульманина или мусульманки, сами подстраиваются под него.

В целом, неприятие современного светского стиля жизни (полного, по мнению верующих, пороков и критики в адрес мусульман), приводит к:

- созданию мусульманских, в некотором роде альтернативных современному культурному и молодежному мейнстриму публичных пространств: кафе, клубов, молодежных и детских лагерей

- и стилей занятости, например, на предприятиях, созданных мусульманами, предполагающих соблюдение всех канонов.

Одновременно в редких интервью прослеживается установка на закрытый образ жизни, когда некоторые мусульмане говорят, что стараются общаться и выстраивать дружеские связи и знакомства в среде своих соверующих. Большинство же наших опрошенных утверждали, что, хотя в их ближайшем окружении больше мусульман, они поддерживают дружеские, рабочие контакты, знакомства и с неверующими сверстниками, и с представителя других религий.

И, наконец, пятый, концептуальный компонент религиозности, выражается в следовании заложенной догматикой установке на обретение знаний. Практически все мусульмане, с кем мы общались вне стен религиозных заведений, либо уже получили на каком-то из уровней религиозное образование, либо получают его. Установка на совмещение светского и религиозного образования широко распространена среди современных молодых мусульман, особенно среди девушек. Более того, даже уже окончив медресе, большинство продолжает пополнять 
свои знания через чтение литературы или посещение публичных лекций, встреч или путем личных консультаций со «знающими людьми».

В заключение хотелось бы сделать несколько методологических обобщений. Во-первых, очевидна принципиальная «несочетаемость» двух методик, как в самой «механике» и «оптике», так и в языке описания данных. Обращение к результатам массового опроса заставляет исследователя мыслить «относительными величинами», «процентами» сквозь призму которых уже не проследить конкретных жизненных судеб респондентов, их жизненных смыслов. Метод массового социологического опроса при всей сложности его организации, примененный к такому неоднозначному явлению, как религиозная жизнь человека, оказывается грубым и «несензитивным» к нюансам. Он относится к опрашиваемому лишь как к набору интересующих исследователя свойств - т.е. предполагает неравные субъект-объектные отношения. В лучшем случае он позволяет детально зафиксировать идентификационную и поведенческую компоненты религиозности, и реже - концептуальную (т.е. проверить знание некоторых доктринальных основ и пр.). Качественные же методы в силу своей сензитивности к жизненному опыту верующего позволяют показать его в многообразии, однако не способны вывести исследователя на уровень высокой степени генерализации настолько, чтобы дать ожидаемый ответ на «социальный заказ», с которого мы начали наши рассуждения.

Вторым и, наверное, самым значимым является наблюдение, что обе методологические парадигмы не свободны от «нормативного идеала». Под ним мы понимаем установку как самого исследователя, так и исследуемых на воспроизводство нормативного образа верующего (в нашем случае мусульманки или мусульманина), формируемого и транслируемого религиозными институциями в соответствии с религиозными догматами и принятыми в сообществе верующих правилами и регулярностями поведения. Однако механизм включения этого нормативного образца в исследовательскую оптику в этих методах несколько различен. В случае массового опроса он прежде всего «вписан» в инструментарий анкетного опроса, когда исследователь заведомо знает, во что должен верить и как следует вести себя мусульманину или мусульманке. Одновременно здесь также имеется слабое следование нормативному идеалу и со стороны респондентов. Так, специфика религиозной ситуации в российском обществе такова, что сегодня нормативно иметь религиозную идентичность, нежели не иметь ее вовсе. Этим и объясняются 8-9 \% тех, кто причислил себя к исламу, но назвался неверующим, или 17 \% этой же группы, не указавшей свою веру в Бога, или треть «мусульман», не назвавших ни одного мусульманского ритуала или обряда, которому они когда-либо следовали и т.д. В качественных же методах, основанных на общении с изучаемыми людьми, «нормативный идеал» транслируется прежде всего последними. На ма- 
териалах интервью мы смогли получить, и это явствует из нашего изложения, в основном лишь идеальный образ молодого мусульманина и мусульманки, некий моральный ориентир для тех, с кем мы беседовали. Устные беседы и интервью позволяют молодежи арктикулировать собственные стремления следовать этому морально-нравственному образцу. Насколько успешным оказывается этот путь, мы судить не можем, поскольку ограничены опросным методом. Мы же в основном располагаем косвенными данными об отклонении от идеального образа мусульманина, однако, учитывая нежелание наших собеседников рассказывать неблагоприятную информацию о ком-то и их сдержанность в оценках, распространенность иных «ненормативных» моделей поведения мусульман остается неизвестной. В любом случае мы не склонны идеализировать практикующую мусульманскую молодежь. Не все из них вербализуют нормативно приемлемые для сообщества паттерны поведения. Некоторые собеседники, напротив, рассуждая вполне искренне, декларируют иные рациональности в актуализации религиозной идентичности. Кроме того, мусульманская молодежь в целом неоднородна. Она сегментирована по возрасту, уровню образования, месту жительства. Некоторыми их религиозность рассматривается как некий ресурс, позволяющий «обменять» его на иные ресурсы (практические, символические и пр.). Возможно, для некоторых молодых людей и девушек из сел или дальних и/или депрессивных районов обретение мусульманской идентичности видится неким «социальным лифтом», позволяющим получить доступ во взрослой жизни к устойчивому социальному окружению.

Преодоление влияния нормативного идеала чрезвычайно сложно и полностью невозможно ни в одном из методов. В качестве альтернативного пути мы предлагаем не только учет «несовпадения» ответов и рассказов и догматически обоснованного идеала, но также понимание и описание типов религиозного сознания и моделей обращения к вере. В любом случае описание подобных методических трудностей будет первым шагом не только к исследовательской саморефлексии, но также к осознанию подобной проблемы другими заинтересованными агентами «социального заказа» - лидерами религиозных сообществ, государственными чиновниками и т.п. Если исследователи будут открыто обсуждать не только результаты опросов, но также раскрывать «кухню» получения данных, то задача определения доли мусульман в России в целом или отдельном ее регионе (например, Татарстане), перестанет быть проблемой практической, а станет дискуссионным полем, в котором должны быть озвучены не один, а множество ответов, и вместо конкретной цифры должны быть предложены различные типологии верующих. 


\section{Источники и литература}

Гараев, 2008 - Гараев Д.М. Практикующие мусульманки в современной Казани: биографии, практики и идентичность: Магистерская работа. СПб., 2008.

Каариайнен, Фурман, 1999 - Каариайнен К., Фурман Д. Татары и русские - верующие и неверующие, старые и молодые // Вопросы философии. 1999. № 11. С. 68-80.

Каариайнен, Фурман, 2007 - Новые церкви, старые верующие - старые церкви, новые верующие / Под ред. К. Каариайнена, Д. Фурмана. М.-СПб., 2007.

Коробко, 2009 - Коробко Р.О. Оценка численности прихожан православных церквей г. Тюмени // Материалы VII международной конференции Московского религиоведческого общества «Будущее религии в Европе» 14-16 мая 2009 г.

Мусина, 2007 - Мусина Р.Н. Процесс ре-исламизации и проблемы идентичности татар в постсоветский период// Современная татарская нация: концептуальные исследования. Казань, 2007. С. 177-186.

Сабирова, 2008 - Сабирова Г.А. Мусульманские идентичности и дискурсивная традиция ислама в постсоветской России // Традиции и инновации в современной России: Социологический анализ взаимодействия и динамики. М., 2008. С. 457-494.

Филатов, Лункин, 2005 - Филатов С.Б., Лункин Р.Н. Статистика российской религиозности: магия цифр и неоднозначная реальность // Социологические исследования. 2005, № 6. С. 35-45. 